\title{
TTL wt Allele
}

National Cancer Institute

\section{Source}

National Cancer Institute. TTL wt Allele. NCI Thesaurus. Code C97865.

Human TTL wild-type allele is located in the vicinity of $2 q 13$ and is approximately $50 \mathrm{~kb}$ in length. This allele, which encodes tubulin-tyrosine ligase protein, plays a role in the posttranslational modification of tubulin. 